\title{
Coherences and Contingencies in the Reformed and Evangelical Theology: Dialectical Relation between Identity and Flexibility
}

\author{
Chandra Gunawan \\ Theologische Universiteit Kampen \\ Email: rev.chandragunawan@gmail.com
}

\begin{abstract}
Hermeneutics has an important role in the theological studies and has led many denominations, including the Reformed and evangelical churches, to re-evaluate how they should develop their theology in the postmodern context. This essay analyzes two characteristics of the early church namely her coherence and contingency and shows that the Reformed and Evangelicals should maintain these basic elements that she could be relevant to her contemporary without losing her identity. Contextual analysis and background analysis will help understand how the early church and fathers develop their theologies in their contexts. This study finds that hermeneutics is fundamental for theological schools in developing their subjects and for church ministries in educating her congregation; therefore, the Reformed and evangelicals should consider this discipline so that she enables properly re-contextualizing the historic tradition in this pluralistic context.
\end{abstract}

Keywords: coherence, contingency, hermeneutics, early church, Reformed, Evangelicals, historic tradition, context

\begin{abstract}
Abstrak
Hermeneutika memiliki peran penting dalam studi teologis dan telah memimpin banyak denominasi, termasuk gereja-gereja Reformasi dan evangelikal, untuk mengevaluasi kembali bagaimana mereka harus mengembangkan teologi mereka dalam konteks postmodern. Artikel ini menganalisis dua karakteristik gereja mula-mula yaitu koherensi dan kontinjensi dan menunjukkan bahwa kaum Reformed dan Evangelikal harus mempertahankan elemen-elemen dasar ini agar ia dapat relevan dengan kontemporernya tanpa kehilangan identitasnya. Analisis kontekstual dan analisis latar belakang akan membantu memahami bagaimana gereja mula-mula dan para ayah mengembangkan teologi mereka dalam konteks mereka. Studi ini menemukan bahwa hermeneutika adalah dasar bagi sekolah-sekolah teologis dalam mengembangkan mata pelajaran mereka dan untuk pelayanan gereja dalam mendidik jemaatnya; oleh karena itu, Reformed dan evangelis harus mempertimbangkan disiplin ini sehingga ia memungkinkan kontekstualisasi tradisi historis dengan tepat dalam konteks pluralistik ini.
\end{abstract}

Kata kunci: koherensi, kontingensi, hermeneutika, gereja mula-mula, Reformed, Evangelis, tradisi bersejarah, konteks

\section{Introduction}

There is no perfect church in this world. The reformed and evangelical churches also do not immune to this deficiency, struggling with some serious problems, in particular, handling the diversities among them. According to Cressey, for instance, refor- 
med churches has "disagreed among themselves about the use of creeds and confessions to test the orthodoxy of members and ministers, but they have always emphasized the

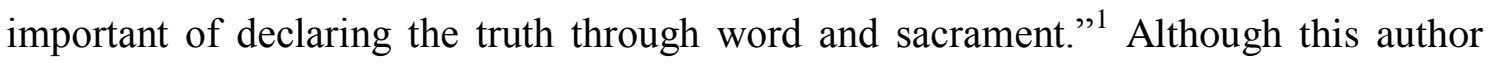
probably exaggerates the case because the disagreement is presumably diversities in the Calvinistic churches, ${ }^{2}$ it may lead to disputation and separation. On the other hand, the evangelical churches face a different issue, which, according to Ben Witherington III, fails to be "grounded" in the biblical teaching and its theology; ${ }^{3}$ he says: "[w] hat I see in the church's proclamation, and in what passes for its theology, are not just glaring weaknesses but real problems of exegesis."

Hermeneutics will play a vital role in improving the Reformed and Evangelical churches. It works not only as an academic discipline imposing rules for biblical interpretations but also as guidance for believers to develop a good understanding. ${ }^{4}$ It has two basic functions within the body of Christ, namely, as the exegetical tool that enables Christians reading and understanding biblical messages in a way that is appropriate and as the art of understanding which contributes to congregations in emphatically reading and listening any subject, especially the Christian tradition. ${ }^{5}$ Since this develops in its historical context that is usually polemical in essence, ${ }^{6}$ hermeneutics will help to comprehend the tradition in its context, learning that Christian belief is not static, improving it so that it becomes relevant to the present time, respecting different understanding among Christian communities.

Although modern hermeneutics has challenged the Reformed and Evangelicals to develop a model of interpretation which are more emphatic, in which listening and understanding are considered as important as defending a belief system, this approach may lead Christians to changes not only their hermeneutical reading on Scripture and

1 M. H. Cressey, "Reformed/Presbyterian Churches," in Dictionary of the Ecumenical Movement, ed. Nicholas Lossky et al., (Grand Rapids: Eerdmans, 1991), 851-852.

${ }^{2}$ Some evidence suggests that the Reformed churches attempt to preserve and to restore unity among their communities. For example, nowadays Netherlands Reformed churches try to find commonalities that enable uniting their churches. Compared to the early church, diversity and unity create a community with a unique character (see, e.g., Eph. 2.11-22), treating the Gentiles and Jews as one family, serving God together.

${ }^{3}$ See Ben Witherington III, The Problem with Evangelical Theology: Testing the Evangelical Foundations of Calvinism, Dispensationalism, and Wesleyanism (Waco: Baylor, 2005), ix.

${ }^{4}$ Anthony C. Thiselton, Hermeneutics: An Introduction (Grand Rapids: Eerdmans, 2009), 1-5.

${ }^{5}$ Ibid. 5-7.

6 James D. G. Dunn and James P. Mackey, New Testament Theology in Dialogue, Biblical Foundations in Theology (London: SPCK, 1987), 44-49. 
Christian traditions but also to influence their understanding on the two. Thiselton stresses that a hermeneutical spiral applied in interpretation will refine interpreters' preunderstanding ${ }^{7}$ consequently, it is also possible that the Christian belief functioning as the pre-understanding in the Christian theology changes by hermeneutical processes that believers try to perform. Nonetheless, RC will lose their flexibility and relevancy if they fail to make an adjustment to this new hermeneutical reading.

Many Reformed and evangelical scholars are aware that the church needs to improve and develop her theology and hermeneutical approach. It is imperative for Reformed and Evangelical churches to re-apply and modify Christian theology, responding the struggle of their contemporary in an effective way. At the same time, RC tries to maintain the principles of the Reformed theology, grounding and structuring their system of theology based on Scripture and historic traditions, which become a coherent element in the Christian theology. Yet, RC also should apply the two in a new context because there are differences between, for instance, the historical contexts of the early Christianity and modern churches, respecting the contingency of biblical teachings and historic traditions. However, it is not possible to employ biblical teachings and historic traditions in another context if there is no flexibility to improve these fundamentals. In this post-modern time, RC should develop a theology that maintains not only its coherence to the historic tradition but also its contingency.

This article will discuss some evidences from biblical teaching and historic traditions that could help modern readers to see how important the coherence and the contingency in the church. ${ }^{8}$ Further, there will be a discussion regarding coherences and contingencies in systematic theology, in practical theology and in missiology. Systematic theology may be solid in maintaining the coherence of the biblical teaching, yet this discipline has a problem with its contingency; this could make systematic theology to be inflexible. In contrast, practical theology and missiology prove particularry strong in their contingency, yet they need to maintain the coherence of the biblical teaching and historic traditions so that the two subjects will consistently develop their discipline without ignoring biblical teaching and historic traditions that forms the identity of the

\footnotetext{
${ }^{7}$ Thiselton, Hermeneutics, 13-16.

${ }^{8}$ In this article, the term "historic tradition" refers to fundamental teachings in Christianity such as the confession of trinity, which is rooted in the biblical theology.
}

The New Perspective in Theology and Religious Studies, Vol. 1, No. 1, 2020 - 57 
Reformed church and her ministries. Lastly, we will discuss how the Reformed and Evangelicals could maintain her identity and her flexibility in our present situation.

\section{The Coherence and Contingency in the Biblical Theology and the Historic Tradition}

Dunn correctly describes the New Testament (NT) theology as a dialogue between descriptive and prescriptive approaches; he also emphasizes that NT theology does not only expound the theology of the NT authors but it tries to build a theology through NT teachings. Further, he shows some problems that occur in NT theology: (i) the fragmented sources, (ii) theological diversity between the authors, (iii) an unclear unity between the authors. ${ }^{9}$ Similar issue could be found in biblical theology; although this subject attempts to discover a unity in the OT and the NT, yet there are still enormous diversities in the two testaments. ${ }^{10}$ Surely, these diversities do not indicate that some contradictions exist in the biblical teaching. In contrast, they basically exemplify that these biblical teachings were given in certain contexts; in other words, the diversities in biblical teachings show that the scriptural principle has its own contexts. On the other hand, since diversities between the authors basically are not contradictory, but they complement one another, there is the legitimate reason to read these different teachings in light of canonical view, to wit, reading these texts as the Scripture.

The concept of justification could be a good example for elucidating this issue. This teaching has an important role in Christianity both in past and present; this doctrine is rooted in the OT and was discussed by Paul, Augustine, Luther and contemporary scholars. Stendahl, for instance, argues against the traditional and Protestant view that reading this concept from the purview of Augustine and Luther, who have different contexts and situations from Paul the Apostle, is misguided. ${ }^{11}$ He may be correct that using Augustine and Luther's perspective to read Paul's teaching on justification is anachronistic; however, Augustine and Luther's understanding on justification still can be seen as an effort to re-apply this postulation to their contexts.

\footnotetext{
${ }^{9}$ Dunn \& Mackey, New Testament 1-12.

${ }^{10}$ Cf. I. H. Marshall, New Testament Theology (Downers Grove: IVP, 2004), 44-46.

${ }^{11}$ Krister Stendahl, "The Apostle Paul and the Introspective Conscience of the West," HTR 56 (1963): 199-215.
}

58 - The New Perspective in Theology and Religious Studies, Vol. 1, No. 1, 2020 
In the context of Galatians, Paul clearly applies the teaching about justification to handle the relational and social issues between Jewish and gentile Christians. The literary context of this letter indicates that the issue of circumcision (e.g., Gal. 6.12) is behind the controversy among the Galatians, and this problem is relating to another fundamental issue: a religious identity. ${ }^{12}$ The congregation probably has a vital question regarding how they know that an individual is truly God's people. Paul applies the notion of justification to maintain that true Christian identity does not depend on outward marks such as circumcision (see e.g., Gal. 5.6) but on the the faith of Christ.

This doctrine of justification is evidently not created by Paul. This teaching occurs in the OT, and Paul seems to adopt, to re-apply and to modify this tradition. To illustrate, Paul uses the story of Abraham to explain how God justify an individual; this case exemplifies that the concept of justification has been taught since Abraham lived; Paul only reformulates this concept in accordance with his experience with Christ and modifies it to a situation faced by his readers so that it could help congregation handle their problem. Further, in his letter to the Romans, Paul keeps the principle of Justification in the OT; similar to this first testament, Paul also teaches the doctrine of Justification in its relation to both God's righteous judgment and his faithful act; the apostle then re-applies it to the new context such as in the letters the Romans (cf. Rom 1.18-3.31). ${ }^{13}$ This proves that Paul's teaching on justification has coherent and contingent elements.

The same pattern can be seen in the theology of justification that is developed by Augustine and Luther. Augustine makes use of Paul's teaching about Justification and re-applies it to the issue in his times. He develops and employs this doctrine in accordance with his reaction to the philosophical teachings developed by Simplicanus and Pelagianism; in other word, the teaching about justification was improved and modified by Augustine to answer the question of his contemporaries. ${ }^{14}$ Similarly, to answer the question that is asked by via moderna about how a person should respond God's grace so that they could receive justification from God, Luther has improved the concept of justification that he learns from Paul and Augustine. ${ }^{15}$

\footnotetext{
12 J. D. G. Dunn, New Perspective on Paul , rev.ed. (Grand Rapids: Eerdmans, 2008), 114-115.

13 Cf. M. A. Seifrid, "Righteousness Language in Hebrew Scriptures and Early Judaism." Justification and Variegated Nomism Vol. 1, WUNT 2.140 (Tübingen: Mohr Siebeck, 2001), 415-442.

${ }^{14}$ A. E. McGrath, Iustitia Dei (Cambridge: Cambridge University, 1998), 24-27.

15 A. E. McGrath, Luther's Theology of the Cross (Oxford: Blackwell, 1985), 61, 100-113.
} 
Therefore, while differences between Paul, Augustine and Luther in formulating the concept of Justification are self-evident, it is also important to notice that they still maintains its coherence. For example the three believe that the justification comes from God and that the true faith in Christ is the only manner that enables people receiving God's grace, the salvation. They are not opposing one another; they have different emphasis because they face different issues and have different contexts; they need to reapply and modify the teaching so that it could be relevant to their contemporaries.

\section{The Coherence and Contingency in Systematic Theology, Practical Theology and Missiology}

According to Ganzevoort, in every religion there are three elements that is inextricable i.e., a teaching derived from sacred writing, the tradition and the praxis. ${ }^{16}$ In the Christian terminology, these elements are called biblical teaching, dogma and practical theology. This section will discuss the second and third elements of this religious construction.

Contemporary Christian dogmatics faces a tough challenge from a cultural change. The influence of Christianity in the world that decreases and increasing of other movements such as atheism, postmodern self, Islam, etc., push Christian dogmatics to present its teaching in a way that is more significant in the context of pluralistic world but still able to answer challenges of our times. ${ }^{17}$ Additionally, there is also an internal problem that the Christian dogma seems to have no significant impact in the struggle and the life of Christians in this modern society. ${ }^{18}$

It is not easy for dogmatics to answer these challenges. It is caused that the historic tradition, which is inherited from church fathers, reformers, etc., was not arranged to answer questions of our time. Mackay believes that systematic theology (dogmatics) involves the study of the biblical teaching and historical milieu in which a dogma is developed. ${ }^{19}$ Mackay shows that the dogma is not developed out of context, for instance the doctrine of God and Christ in the apostolic creed was developed in the

\footnotetext{
16 R. Ruard Ganzevoort, "Forks in the Road When Approaching the Sacred," 2009 (www.ruardganzevoort.nl)

17 Hans Burger, Being in Christ (Eugene: Wipf \& Stock, 2008), 4-5; A. C. Thiselton, Interpreting God and the Postmodern Self (Edinburg: T \& T Clark, 1995), 3-9.

${ }^{18}$ Cf. C. E. Gunton, The Promise of Trinitarian Theology, 2nd.ed. (Edinburgh: T \& T Clark, 1997), 1-4.

${ }^{19}$ Dunn \& Mackey, New Testament in Dialogue, 28-32.
}

60 - The New Perspective in Theology and Religious Studies, Vol. 1, No. 1, 2020 
context of the platonic teaching; moreover he also shows that the dogma's development is polemic in essence. ${ }^{20}$ Mackey's first point that the dogma is related to a philosophy needs to be considered because the philosophy does not only become the context of the dogma, yet it is also used in approaching, understanding and forming a dogma. ${ }^{21}$ On the other hand, Mackey might have been generalizing the formation of a dogma because there is the possibility that the dogma also was used in a non-polemic context such as in catechism, but his point that the formation of a dogma is also related to a particular issue faced by Christians in their times needs to be considered when we understand a dogma and use it to respond challenges of our times.

Although a dogma is bound in its historical context, it still has a coherent element and needs this element. Without coherence, a dogma will lose its function, and this will lead Christians losing their identity and connection to previous Christian generations. And the effort to understand a dogma in its historical context should not relativize it; although there is occasionality in its context, yet there is still the absolute element namely principles from a biblical teaching in the dogma. Therefore, we cannot separate a coherent element of a teaching from its contingency; in fact, we have to understand a dogma in its historical context before we could reapply and modify it to a new context such as in our context.

Similar to systematic theology, the third element of the Christian religion, namely practical theology, also faces similar challenge. Although this subject actually has an important role to re-apply both the biblical teaching and the dogma to the contemporary life, it also faces tough questions from the cultural change. Issues that need to face on this study are not only related to the ethical or practical issues such as addiction, marriage, etc., but it also has to face the fundamental issues of the study itself such as definition, methodology, etc.

Ganzevoort describes that these culture ${ }^{22}$ and religious changes lead practical theology toward the divergences at least in four aspects i.e., (i) in relation to the object of the study (Christian or Religion in general), (ii) in relation to the methodology, (iii) in

\footnotetext{
${ }^{20}$ Ibid, 38-43.

${ }^{21}$ Cf. Gunton, The Promise, 86-100.
}

22 There are three cultural aspects that influence the growing study of practical theology according to P. Ballard and J. Pritchard i.e., (i) the decrease of Christianity, (ii) the increase of social science, (iii) awareness of the necessary of context. Practical Theology in Action (London: SPCK, 1996), $3-4$.

The New Perspective in Theology and Religious Studies, Vol. 1, No. 1, 2020 - 61 
relation to the subjectivity of observer (believer, practitioner or distanced observer), (iv) in relation to the audience (believer, society or academia). ${ }^{23}$ What is more, Ganzevoort sees that there is a common ground in practical theology; he believes that there are three features that mark practical theology i.e., (i) it is always related to religion, (ii) it has a focus on how to relate the teaching-tradition deriving from the sacred writing and the practical live, (iii) it is involving hermeneutical process. ${ }^{24}$ Based on these, he defines practical theology as "tracing the sacred in spiritual, empirical-reconstructive, and critical-constructive mode." 25

To build an effective practical theology that gives a significant impact to the modern society, practical theologians need to work together with systematic theologians and biblical theologians so that a gap between biblical teaching and contemporary context could be bridged; and a good hermeneutics will give some contribution. And social science attracts many practical theologians to use it as the main tool both to interpret the biblical teaching and to apply the biblical teaching to a new situation. ${ }^{26}$ What is more, it is important to be aware that an ancient society is different from a modern society. In addition, although there are similarity between Christian community and others, the Christian Community has a unique character compared to the general society, and therefore, we need to be careful to apply a modern and general approaches such as social science to a particular community, specifically the early church and modern Christian community. To understand both the Christian community and the modern society, it is important that the practical theologians use social science in light of the biblical teaching on humanity and society. ${ }^{27}$ The biblical teaching that influences methodologies used and practices of practical theology will keep the coherence element of the biblical teaching, the historic tradition, and the Christian dogma in practical theology but still have ability to develop its theology and contribution. ${ }^{28}$

In the context of Christian life, the biblical teaching, the historic tradition and the dogma also need to be shared to other people including to them who have different

${ }^{23}$ Ganzevoort, "Forks in the Road"; Cf. Ballard and Pritchard, Practical, 15-25.

${ }^{24}$ Ganzevoort, "Forks in the Road."

25 Ibid.

${ }^{26}$ There is a theological approach that could be used to bridge the gap i.e., "theological narrative framework." Cf. C. Bartholomew, "in front of the text," in The Bible in Pastoral Practice (GR: Eerdmans, 2005), 135-152.

${ }^{27}$ K. J. Vanhoozer shows the necessity to understand non-theological approach in the theological worldview. First Theology (Illinois: IVP, 2002) 207-235.

${ }^{28}$ Practical theology needs to become a descriptive and prescriptive discipline. 
culture from us. The study of Christian missiology deals with this subject. ${ }^{29}$ This study tries to reapply the biblical teaching, the historic tradition and the dogma to a new context. This is not an easy task; Hiebert shows that the cultural issues in missiology are complicated. For example, a missionary has to deal with material, expressive, and ritual culture that are not neutral; although culture does not always contradictory to biblical teachings, yet there are also some "corporate and cultural sins" in certain culture. Therefore, an uncritical contextualization will lead to syncretism. At the same time, if a missionary rejects all local cultures, this will also arise a problem because a "cultural vacuum" could make people lose their identity. ${ }^{30}$

Hiebert proposes a critical contextualization as the solution for these cultural issues in missiology. He underscores that a missionary need to help local churches understand and evaluate their own cultures in the light of biblical teaching, and if it is needed, a missionary also needs to help them modify or reconstruct their own cultures. To do this, a missionaries have to understand biblical teaching, the historic tradition and the dogma in its historical contexts so that they could help the local church to apply the biblical teaching in a correct way and also help them to avoid copying "the culture" of people who was live in the biblical times or in the dogma formation. ${ }^{31}$

\section{Between the Identity and Flexibility}

The Reformed and evangelical theology should be rooted in the biblical theology, should respect the historic tradition, and should maintain its flexibility to be reapplied in a new context. Dunn emphasizes the important of contexts and critical thinking in developing the NT and biblical theology; Mackey underscores necessity to be emphatic and listening others in developing a theology; Thiselton also underlines how significant the spiral process to refine interpreter's understanding. ${ }^{32}$ Criticality and ability to listen others are two leading aspects that need to be maintained and develop in the Re-

${ }^{29}$ The post-colonial approach in hermeneutics leads theological scholarship to be aware and respect a difference of reading scripture done by different readers (it is also call "reading from below"). G. L. Green, Global Theology (Illinois: IVP, 2012), 50-63.

${ }^{30}$ P. G. Hiebert, Anthropological Insight for Missionaries (GR: Baker, 1985), 171-186.

${ }^{31}$ Green suggests three rules to determine whether a teaching is rooted deeply in cultural context: (i) "determine the relative amount of emphasis given a subject in the biblical witness," (ii) "determine the degree to which the biblical witnesses are uniform and consistent on a given issue," (iii) "determine the degree to which a writer's cultural situation provides him/her with only one option (limited options) which to work. Green, "Practice reading of New Testament," HNT, 1st.ed. (GR: Eerdmans, 1995), 425.

${ }^{32}$ Dunn \& Mackey, New Testament, 12-18, 44-49; Thiselton, Introduction, 13-16. 
formed scholarship; it is important to be critical in understanding our own tradition that is bound in its context and in using a new approach to reapply the biblical teaching and theology to our context. To do this there are some suggestions to be considered.

First, we have to find a principle that is rooted in the biblical teaching and is preserved by the historic tradition and become the identity of Christianity. Burger proposes "being in Christ" as the important theme that could lead Christians to reconsider the importance of Christ in modern theology and Christian community; he says:

Reflection on this theme [being in Christ] may show that it is a theme with a great integrating power. If it can be shown that 'being in Christ' embraces Christology, pneumatology, spirituality, biography, and ethics, a concept of 'being in Christ' can be used to do justice to a post-Barthian agenda without losing Christology. Further it might be used to bridge the gap between the past and the present. ${ }^{33}$

The concept of "being in Christ" is important in Paul's and John's teaching; and it may be used as the principle in the Christian theology. However, it is arguable whether the concept of 'being in Christ' become the underlying teaching of the early church since the beginning of the early church. At Antioch the disciples and the followers of Jesus were called Christians (Acts 11.26); the reason that they were called Christians was related to Jesus who is believed as the Christ; this belief, according to Barnett, is rooted in the Peter's preaching in Jerusalem (Acts 2) and also become the core of the gospel in Paul's ministry (1 Co. 15.3). ${ }^{34}$ In the Paul's teaching, the concept of "being in Christ" is prominent and had been existed in the earliest letter (Ga. 3.28-29) ${ }^{35}$ The problem is that while the concept of "being in Christ" and "believing in/on Jesus the Christ" are closely related, both are not identical. ${ }^{36}$ Since the concept of "believing in Jesus the Christ" and the concept of "being in Christ" are closely related, both should be seen as an inseparable biblical teaching; then, we probably could propose both as the principle of Christianity that should unite churches.

Second, the Reformed scholars need to make a dialogical conversation between (i) the biblical teaching, the historic tradition, and the contemporary context; (ii) between biblical theologians, systematic theologians, practical theologians and

\footnotetext{
${ }^{33}$ Burger, Being, 3.

${ }^{34}$ Cf. P. Barnett, The Birth of Christianity (GR: Eerdmans, 2005), 79-94, 184-186.

${ }^{35}$ Further discussion on Galatians, see on Barnett, The Birth, 206-210.

${ }^{36}$ Ben Witherington III, "Christ," DPL (Illinois: IVP, 1993), 98-99; L. Morris, "faith," DPL, 285; R. T. France, “faith,” DJG (Illinois: IVP, 1992), 225.
} 
missionaries. To do the first, a careful and creative biblical interpretation is needed; ${ }^{37}$ secondly, it is important to let the biblical teaching and theology, which are resulted from a good biblical interpretation, broadening and refining our horizon including our theological heritages. ${ }^{38}$ When we find that our theological heritages are different from the biblical context, it is important to understand them in their historical context, and to learn how Christians use that biblical teaching to respond an issue in their times; thirdly, by learning from the biblical teaching and other Christians in the past, we could learn how we should answer our contemporary issue. Similarly, the Reformed theology needs to make interdisciplinary dialogue (biblical studies, systematic, practical theology and missiology); ${ }^{39}$ since there is a potency that Christian theology becomes Christian theologies because each subject wants to be more independent, ${ }^{40}$ the Reformed theology, while respecting its unique character of each theological discipline, needs to keep the unity between them.

Third, we need critically to use a method. It is important that we have flexibility in the method used such as social science, linguistics, etc., because human thought basically comes from God's common grace, yet it does not mean that all methods are neutral and can be applied in the Christian theology because sin affects all human and infects every part of humanity including human thought. ${ }^{41}$ Contemporary hermeneutics is influenced by the postmodern philosophy; while it is important that in the context of making a good interpretation, we are emphatic and able to listen, yet it does not mean that we may be tolerant of the truth. Additionally, there is nothing wrong to be zealous in truth and using polemical way to defend our belief.

The critic from the postmodern self that a religion (a theology) could potentially use a tradition/teaching as a forcing power needs to be heard. ${ }^{42}$ It reminds us to be critical to ourselves, and watching our vested interest in an interpretation. At the same time,

${ }^{37}$ Green shows that NT interpretation involves not only an author, a text and a reader, but also contexts that are existed and influences the author, the text and the reader. "The Challenge of Hearing the New Testament," HNT, 2nd.ed. (GR: Eerdmans, 2010), 1-14.

${ }^{38}$ Cf. Dunn \& Mackey, New Testament, 20-22.

${ }^{39}$ Marshall emphasizes that NT theology is "missionary theology"; consequently, NT theology should be understood in the light of this perspective. New Testament, 34-37. Therefore, it is important to understand that missiology and biblical theology is not separated.

${ }^{40}$ Cf. Ballard and Pritchard, Practical Theology, 4- 5.

${ }^{41}$ Cf. M. Silva \& R. Kaiser, An Introduction to biblical Hermeneutics (GR: Zondervan, 1994), 259.

${ }^{42}$ A. C. Thiselton, Interpreting God and the Postmodern Self (Edinburg: T \& T Clark, 1995), 39. 
it is also important to distinguish between a concept of authority and a violent power; the truth must have a kind of "forcing power," but it does not mean that the truth have to be exercised in harshness. To respond the critic from postmodern self, Thiselton has shown that biblical theology is not and should not become an abusive power because: ${ }^{43}$

... the cross of Christ in principle shatters the boundaries and conflicts between Jew and Gentile, female and male, free person and slave. Moreover the resurrection holds out the promise of hope from beyond the boundaries of the historical situatedness of the postmodern self in its predicament of constraint. The claims to truth put forward in Christian theology, therefore, call for love where there is conflict, for service where there are power-interests, and for trust where there is suspicion.

\section{Conclusion}

It is clear that diversity and unity are the unique character of a church in the past and present. In the early church, we discover that Peter and Paul are different in responding a social issue between Jews and Gentiles (cf. Gal. 2.11-14); in fact Peter and Paul have different missionary vision (cf. Gal. 2.7). On the other hand, there is also unity between Paul, Peter and other apostles, especially in understanding Jesus as the Christ (cf. 1 Co. 15.3-4). Therefore, diversity in the Reformed church should be properly managed so that it could enrich our teaching and tradition and not lead to separation. In this case, I believe that a new emphasis in hermeneutics (listening and understanding) will play an important role and give major contributions in re-applying and modifying the principle of the biblical teaching and the historic tradition to our culture.

The Coherence and the contingency of the Christian teaching should not be separated, and both elements need to be preserved and developed in the Reformed and Evangelical theology. The early church is our model in developing a theology that is consistent and relevant. Both elements will help the Reformed church to maintain and to keep the principles (for instance: the concept of "believing in Jesus the Christ" and "being in Christ") that are underlying Christianity in past and present, yet still have flexibility to adopt a change needed to reapply and to modify our theology so that it will be more relevant to our situation.

There is still other questions that need to be discussed. For instance, how should the Reformed and Evangelical theology represent a theology that could be accepted by

\footnotetext{
${ }^{43}$ Ibid, 42-43.
} 
other denomination without losing her identity? How could the Reformed and Evangelical theology become Christian theology?

The Reformed and Evangelical theology also needs to emphasize that the starting and the end point of reconstructing theology are due to the church and on the sake of the church. Burger suggest some important perspectives related to a good theology i.e., (i) "react adequately to the demands of context," (ii) "stand in continuity with the tradition," (iii) "do justice as comprehensively as possible to the relevant biblical material," (iv) "be conceptually coherent and as consistent," (v) "result in recommendations for the practice of the church." 44 While academic studies may separate between practical and academic issue, the Reformed theologians should emphasize that theological studies is both academic and practical; ${ }^{45}$ and John Calvin could become a good example for showing how a theology should be mainly used to edify church members. ${ }^{46}$ Therefore, it is important for theologians to respond not only theological or philosophical issues but also to invest their times to answer issues that are faced by God's people in our times. ${ }^{47}$

\section{References}

Ballard, P., and J. Pritchard. Practical Theology in Action. London: SPCK, 1996.

Baker. J. C. Paul the Apostle. Minneapolis: Fortress, 1980.

Barnett, P. The Birth of Christianity. Grand Rapids: Eerdmans, 2005.

Bartholomew, C. "in front of the text," in The Bible in Pastoral Practice. Grand Rapids: Eerdmans, 2005.

Burger, Hans. Being in Christ. Eugene: Wipf \& Stock, 2008.

Cressey, M. H. "Reformed/Presbyterian Churches," DEM. Grand Rapids: Eerdmans, 1991.

Dunn, J. D. G. Unity and Diversity. London: SCM, 1977.

Dunn, J. D. G. New Perspective on Paul. rev.ed. Grand Rapids: Eerdmans, 2008.

\footnotetext{
${ }^{44}$ Burger, Being, 24-25.

45 Green ("Practice," 411-427) shows that the aim of reading Scripture will determine an approach and a result of interpretation. Therefore, it is important to read scripture in accordance with the aim in which the text is written (that is, to help the church facing struggles).

${ }^{46}$ Silva \& Kaiser, An Introduction, 254.

${ }^{47} \mathrm{Cf}$. Wayne Grudem, Do We Act as if We really Believe 'that the Bible Alone, and the Bible in its Entirety, is the Word of God Written'?," JETS 43/1 (March 2000), 6-12.
}

The New Perspective in Theology and Religious Studies, Vol. 1, No. 1, 2020 - 67 
Dunn, J. D. G. \& J. P. Mackey. New Testament in Dialogue, BFT. London: SPCK, 1987.

France, R. T. “faith,” DJG. Illinois: IVP, 1992.

Ganzevoort, Ruard. "Forks in the Road When Approaching the Sacred," 2009 (www.ruardganzevoort.nl)

Green, G. L. Global Theology. Downers Grove: IVP, 2012.

Green J. "The Challenge of Hearing the New Testament," HNT. 2nd.ed. Grand Rapids: Eerdmans, 2010.

Green, J. "Practice reading of New Testament." HNT, 1st.ed. Grand Rapids: Eerdmans, 1995).

Grudem, Wayne. "Do We Act as if We really Believe 'that the Bible Alone, and the Bible in its Entirety, is the Word of God Written'?." JETS 43/1 (March 2000), 612.

Gunton, C. E. The Promise of Trinitarian Theology, 2nd.ed. Edinburgh: T \& T Clark, 1997.

Hiebert, P. G. Anthropological Insight for Missionaries. Grand Rapids: Baker, 1985.

Marshall, I. H. New Testament Theology. Downers Grove: IVP, 2004.

McGrath, A. E. Iustitia Dei. Cambridge: Cambridge University Press, 1998.

McGrath, A. E. Luther's Theology of the Cross. Oxford: Blackwell, 1985.

Morris, L. "faith," DPL. Downers Grove: IVP, 1993.

Seifrid, M. A. "Righteousness Language in Hebrew Scriptures and Early Judaism." Justification and Variegated Nomism Vol. 1, WUNT 2.140. Tübingen: Mohr Siebeck, 2001.

M. Silva, M. \& R. Kaiser. An Introduction to biblical Hermeneutics. Grand Rapids: Zondervan, 1994.

Stendahl, K. "The Apostle Paul and the Introspective Conscience of the West." HTR 56 (1963):199-215.

Thiselton, A. C. Hermeneutic: An Introduction. Grand Rapids: Eerdmans, 2009.

Thiselton, A. C. Interpreting God and the Postmodern Self. Edinburg: T \& T Clark, 1995.

Vanhoozer, K. J. First Theology. Downers Grove: IVP, 2002.

Witherington III, Ben. “Christ,” DPL. Downers Grove: IVP, 1993.

68 - The New Perspective in Theology and Religious Studies, Vol. 1, No. 1, 2020 